\title{
Garavellite, $\mathrm{FeSbBiS}_{4}$, a new mineral from the $\mathrm{Cu}-\mathrm{Fe}$ deposit of Valle del Frigido in the Apuane Alps, northern Tuscany, Italy
}

\author{
F. Gregorio, P. Lattanzi, and G. Tanelli \\ Istituto di Mineralogia, Petrografia e Geochimica \\ Università di Firenze, Via La Marmora 4, 50 I I I Firenze, Italy \\ Centro CNR per la Mineralogia e Geochimica dei sedimenti \\ F. VURRO \\ Istituto di Mineralogia e Petrografia \\ Università di Bari, Palazzo Ateneo, 70 100 Bari, Italy
}

SUMMARY. Garavellite occurs in polished sections, as small aggregates, up to $200 \mu \mathrm{m}$ across, of anhedral crystals, usually in direct contact with tetrahedrite, Sbrich bismuthinite, chalcopyrite, and siderite. Chemical formula $\mathrm{Fe}_{0.80} \mathrm{Cu}_{0.02} \mathrm{Sb}_{1.13} \mathrm{Bi}_{0.78} \mathrm{As}_{0.01} \mathrm{~S}_{4}$ on the basis of $\mathrm{S}=4$, or ideally FeSbBiS

The mineral has an orthorhombic unit cell with $a$ $=\mathrm{I} \mathrm{I} .439, b=\mathrm{I} 4.093, c=3.754 \AA, \mathrm{Z}=4$; calculated density $5.64 \mathrm{gm} / \mathrm{cm}^{3}$. Important diffraction lines are 14.00 (m) oIO, $7.08(\mathrm{~m}) 020,3.62(\mathrm{vs}) 230,3.49(\mathrm{~m}) 040,3.34(\mathrm{~m})$ $320,3.20(v s)$ I 2 I, 3. IO (m) 20 I, $2.98(s) 240,2.89(s) 22$ I, 2.63 (vs) $31 \mathrm{I}, 2.5 \mathrm{I}(\mathrm{vs}) 250,2.16(\mathrm{~m}) 42 \mathrm{I}$, I.677 $(\mathrm{m}) 3 \mathrm{I} 2$. In reflected light it is grey with a brown-olive tint similar to that of tetrahedrite. Bireflectance is distinct and anisotropism is also strong, from yellowish-green to bluish grey. Vickers hardness (50 g load) $212-22 \mathrm{~kg} / \mathrm{mm}^{2}$. Reflectance in air: $470 \mathrm{~nm} R_{1}=33.5-34.7 \%, R_{2}=40.5$ $42.8 \%$; $546 \mathrm{~nm} 32.8-34.7 \%, 40.2-42.0 \%$; $589 \mathrm{~nm} 32.6-$ $33.7 \%, 39.3-41.0 \%$; $650 \mathrm{~nm} 32.4-34.6 \%, 38.4-41.0 \%$.

The mineral and name have been approved before publication by the Commission on New Minerals and Mineral Names, IMA.

Frigidite, the so-called nickel-bearing variety of tetrahedrite found at this locality, is shown to be an intergrowth of tetrahedrite and Ni-bearing minerals.

DURING a detailed mineralogical study of the deposit of Valle del Frigido (Apuane Alps, Tuscany), a mineral with the ideal formula $\mathrm{FeSbBiS}_{4}$ has been found. We have named this mineral garavellite in honour of Professor C. L. Garavelli in recognition of his contribution to the field of mineralogy of Tuscan ore deposits. The mineral and name have been approved by the Commission on New Minerals and Mineral Names of the I.M.A.

The deposit of Valle del Frigido is located I $\mathrm{km}$ eastward from the city of Massa, along the banks of the stream Frigido and it was intensively mined till the third decade of this century. The orebodies are formed of spathic siderite with disseminated chalcopyrite. Other minerals present in minor to trace quantities include tetrahedrite, pyrrhotine, pyrite, marcasite, galena, sphalerite, meneghinite, ullmannite, pentlandite, vaesite, bismuthinite, chalcanthite, and quartz. Garavellite appears in polished sections, as small aggregates, up to $200 \mu \mathrm{m}$ across, of anhedral crystals, usually in direct contact with tetrahedrite, Sb-rich bismuthinite$\left(\mathrm{Bi}_{0.75} \mathrm{Sb}_{0.25}\right)_{2} \mathrm{~S}_{3}-$, chalcopyrite, and siderite. The deposit of Valle del Frigido is particularly known in the mineralogical literature for two varieties of tetrahedrite pointed out by Bechi and by d'Achiardi (I88I) at the end of the last century (Manasse, I906; Palache et al., 1944). Bechi's variety, called coppite, is a quite usual Fe-rich tetrahedrite, while d'Achiardi's variety was considered to be a Ni-rich tetrahedrite, and named frigidite. We have electron-probed several areas of this tetrahedrite and we detected no $\mathrm{Ni}$ content over the limit of detectability, $0.07 \mathrm{wt} \%$. This fact linked to the presence, never reported before, of ullmannite, pentlandite, and vaesite strictly associated with tetrahedrite suggests that the so-called frigidite is an intergrowth of tetrahedrite and the abovementioned Ni-bearing minerals.

According to Monetti (1924) and Capuzzi and Carriero (1973), the deposit of Valle del Frigido has a lenticular vein form, $0.40-2 \mathrm{~m}$ thick, concordant with the embedding quartz-sericite schist described by Manasse (I906). The wall rocks belong to the upper part of a complex of detritic sediments, 
Triassic in age, which represent the basement of the so-called 'Paraautoctono Apuano'. The basement was affected by the alpine tectonism and it is characterized by a low grade of metamorphism corresponding to the greenschist facies, dated by $\mathrm{K} / \mathrm{Ar}$ method at I4 Ma (Giglia and Radicati di Brozolo, I970; Trevisan et al., I97 I ; Dallan Nardi and Nardi, 1975).

Carmignani et al. (1972, 1975), to whom the reader is referred for a detailed description of the deposits of the Apuane Alps, pointing out the tectonically undisturbed character of the deposit of Valle del Frigido and of its minerals, suggest an epigenetic post-tortonian age of emplacement with magmatic affiliation linked to an inferred deeply located acid pluton.

Composition. The chemical composition of garavellite has been determined by electron-probe analyses performed on five different grains apparently free from contamination. The PhilipsNorelco AMR/3 electron-probe of the Institute of Mineralogy of Florence operated at $20 \mathrm{kV}$ was used (Tanelli, I970; Corsini and Tanelli, 1974). Standards were pure $\mathrm{Fe}, \mathrm{Cu}, \mathrm{As}, \mathrm{Sb}, \mathrm{Bi}$, and synthetic bismuthinite. Each element in each point was counted three times and the measured concentrations were corrected for atomic number, absorption, and fluorescence using the programme of Duncumb and Jones ( I969), slightly modified. The results of the analyses are summarized in Table $I$, and in fig. I some X-ray images of garavellite are shown. On the basis of $S=4$ the average composition yields the formula

$$
\mathrm{Fe}_{0.80} \mathrm{Cu}_{0.02} \mathrm{Sb}_{1.13} \mathrm{Bi}_{0.78} \mathrm{As}_{0.01} \mathrm{~S}_{4}
$$

or ideally $\mathrm{FeSbBiS}_{4}$. The analyses reveal that $\mathrm{Sb}$ : Bi atomic ratio ranges, at constant sum, from
I.57 to I.3O, apparently to indicate a diadochy of these elements in garavellite. The formula of garavellite appears to be close to that of berthierite $\mathrm{FeSb}_{2} \mathrm{~S}_{4}$, with a slightly different $\mathrm{Fe}: \mathrm{S}$ ratio, which
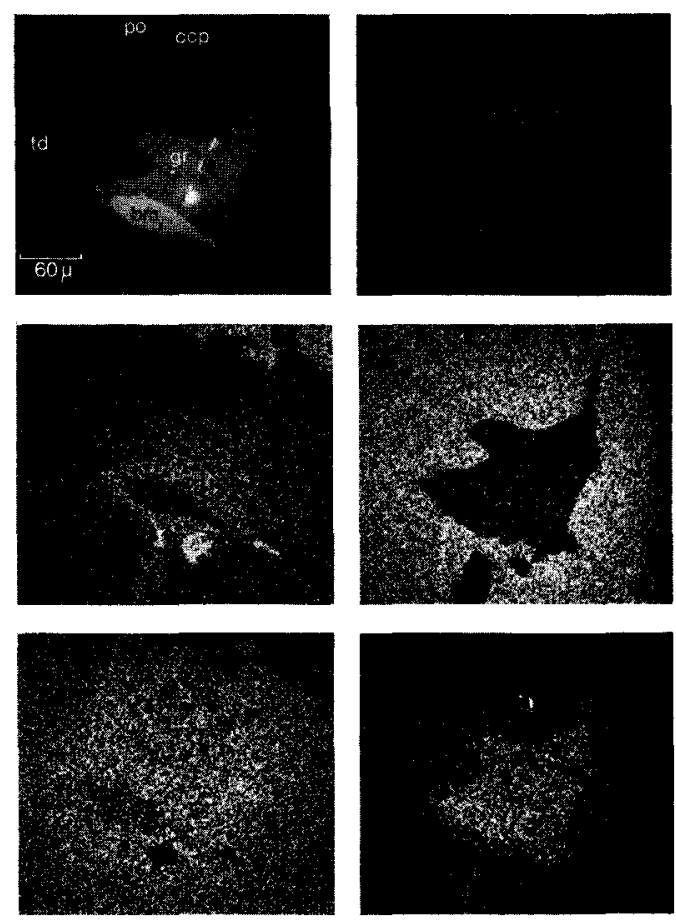

Fig. I. Electron-probe secondary electrons image (top left) and X-ray images of a typical association of garavellite ( $\mathrm{gr}=$ garavellite, $\quad \mathrm{ccp}=$ chalcopyrite, $\mathrm{td}=$ tetrahedrite, $\mathrm{bm}=$ bismuthinite, po = pyrrhotine). Top right, Ni, middle left, $\mathrm{Fe}$; middle right, $\mathrm{Cu}$; bottom left, $\mathrm{Sb}$; bottom right, $\mathrm{Bi}$.

TABLE I. Microprobe analyses of garavellite

\begin{tabular}{|c|c|c|c|c|c|c|c|c|c|c|c|c|c|}
\hline \multirow{2}{*}{$\begin{array}{l}\text { Analysis } \\
\text { number }\end{array}$} & \multicolumn{7}{|c|}{ Weight $\%$} & \multicolumn{6}{|c|}{ Atoms $\%$ (normalized to 100.00 ) } \\
\hline & $\mathrm{Fe}$ & $\mathrm{Cu}$ & As & $\mathrm{Sb}$ & $\mathrm{Bi}$ & $\mathbf{S}$ & Total & $\mathrm{Fe}$ & $\mathrm{Cu}$ & As & $\mathrm{Sb}$ & $\mathrm{Bi}$ & $\mathbf{S}$ \\
\hline Ia & $9.4 \mathrm{I}$ & 0.30 & 0.16 & 29.90 & 33.28 & 27.43 & I 00.48 & I I. 73 & 0.33 & O. I 5 & I7. 10 & I I. IO & 59.60 \\
\hline $\mathrm{Ib}$ & $9.4^{\circ}$ & 0.30 & 0.16 & 29.92 & 33.70 & $27.4 \mathrm{I}$ & 100.89 & II.7I & 0.33 & 0.15 & 17.10 & I I.22 & 59.49 \\
\hline $2 a$ & 9.30 & $0.5 \mathrm{I}$ & O. I4 & 29.77 & 31.91 & 26.67 & 98.30 & I 1.85 & 0.57 & 0.13 & 17.40 & 10.86 & 59.18 \\
\hline $2 b$ & 9.30 & 0.51 & 0.14 & 29.78 & 32.28 & 26.66 & 98.67 & I 1.84 & 0.57 & 0.13 & 17.38 & 10.98 & 59. 10 \\
\hline $3 a$ & 9.34 & 0.05 & 0.22 & 27.49 & 35.91 & 26.93 & 99.94 & I 1.87 & 0.05 & $0.2 \mathrm{I}$ & 16.03 & I 2.20 & 59.63 \\
\hline $3 b$ & 9.33 & 0.05 & 0.22 & 27.50 & 36.30 & $26.9 \mathrm{I}$ & I00.3I & I I. 85 & 0.05 & $0.2 \mathrm{I}$ & 16.02 & I 2.33 & 59.55 \\
\hline $4 a$ & 9.49 & 0.29 & 0.17 & 28.48 & 35.02 & 26.25 & 99.70 & I2. I 6 & 0.32 & 0.16 & I 6.74 & I 1.99 & 58.62 \\
\hline $4^{b}$ & 9.49 & 0.29 & 0.17 & 28.48 & 35.18 & 26.25 & 99.86 & I2.I 6 & 0.32 & 0.16 & I 6.74 & I 2.04 & $58.5^{8}$ \\
\hline $5^{a}$ & 9.24 & 0.28 & 0.17 & 28.80 & 34.10 & $27.3^{6}$ & 99.95 & I I.6 I & $0.3 \mathrm{I}$ & 0.15 & 16.60 & I 1.45 & 59.88 \\
\hline $5 b$ & 9.24 & 0.28 & 0.17 & 28.80 & 3424 & 27.35 & 100.08 & I I.6 I & 0.31 & 0.15 & 16.59 & I I. 49 & 59.84 \\
\hline
\end{tabular}

a. Standards: pure $\mathrm{Fe}, \mathrm{Cu}, \mathrm{As}, \mathrm{Sb}, \mathrm{Bi}$, and $\mathrm{Bi}_{2} \mathrm{~S}_{3}$ for sulphur.

b. Standards: pure $\mathrm{Fe}, \mathrm{Cu}, \mathrm{As}, \mathrm{Sb}$, and $\mathrm{Bi}_{2} \mathrm{~S}_{3}$ for bismuth and sulphur.

Average composition (at.\%): Fe I I.84-Cu 0.31-As 0.I6-Sb I6.77-Bi I I.57-S 59.35. 
could be imputed either to a deficiency of iron or to an excess of sulphur.

To our knowledge, in the $\mathrm{Fe}-\mathrm{Sb}-\mathrm{Bi}-\mathrm{S}$ system there are neither natural nor synthetic strictly quaternary phases, and none of the S-bearing ternary phases, synthetic $\mathrm{FeBi}_{4} \mathrm{~S}_{7}$ (Craig et al., I971; Sugaki et al., I972), gudmundite (FeSbS), and berthierite $\left(\mathrm{FeSb}_{2} \mathrm{~S}_{4}\right)$, enlarge their compositional field in the quaternary system (Palache et al., I944; Ramdohr, 1969; Nowacki, I969; Clark, I966; Craig and Barton, 1973). In particular berthierite which is stable at very low sulphur activity and at temperatures up to $563{ }^{\circ} \mathrm{C}$, according to Barton ( $197 \mathrm{I}$ ), is characterized by a composition matching the ideal formula very well, and a Bi-bearing berthierite has never been reported.

$X$-ray powder diffraction data. The small grain size and occurrence of garavellite as fine polycrystalline aggregates preclude single-crystal investigations. We have tried to synthesize garavellite at 300 and $500{ }^{\circ} \mathrm{C}$, but our attempts, by dry synthesis in silica vessels, were unsuccessful. X-ray powder-diffraction data were obtained using both Debye and Gandolfi cameras. After microprobe analyses and optical investigations, the grains of garavellite were gouged out with the point of a needle, picked up on a glass fibre coated with silicon grease, and mounted in the camera.

In Table II the X-ray powder-diffraction pattern of garavellite, collected using a I I 4.6-mm Debye camera, Straumanis film mounting, and ironfiltered cobalt radiation, is reported. Additional reflections of contaminant siderite were also recorded.

The pattern of garavellite is similar to that of berthierite as reported by Berry and Thompson (1962) and Barton (1971), but includes such lines as I4.00 and $3.77 \AA$, indexed as oIo and $00 \mathrm{I}$ respectively, which violate the space group requirement of Pnam assigned to berthierite (Buerger and Hahn, 1955). The orthorhombic cell dimensions, obtained by the least-squares method, are: $a=$ I I.439 $\AA$, $b=I_{4} .093 \AA, c=3.754 \AA$.

By analogy with the powder-diffraction data, garavellite is presumed to have a defective berthierite-type structure, with one of the two $\mathrm{Sb}$ sites of berthierite occupied by bismuth. The calculated densities of $\mathrm{FeSbBiS}_{4}$ and $\mathrm{Fe}_{0.83} \mathrm{Cu}_{0.02} \mathrm{As}_{0.01}$ $\mathrm{Sb}_{1.17} \mathrm{Bi}_{0.81} \mathrm{~S}_{4.15}$, for $\mathrm{Z}=4$ as for berthierite, are respectively $5.64 \mathrm{gm} / \mathrm{cm}^{3}$ and $5.40 \mathrm{gm} / \mathrm{cm}^{3}$.

Optical features. In reflected light garavellite is grey with a brown-olive tint similar to tetrahedrite. Bireflectance is distinct and more evident in air than in oil. Anisotropy is strong, but not as strong as for bismuthinite, with colours in $45^{\circ}$ positions from yellowish grey to bluish grey. Polishing hardness is higher than bismuthinite, slightly
TABLE II. X-ray powder diffraction data for garavellite

\begin{tabular}{|c|c|c|c|c|c|c|c|}
\hline$h k l$ & $d_{\text {obs }}$ & $d_{\text {calc }}$ & $I$ & $h k l$ & $d_{\mathrm{obs}}$ & $d_{\text {calc }}$ & $I$ \\
\hline olo & I $4.0 \AA$ & $14.092 \AA$ & $\mathrm{m}$ & I 12 & I. $83 \mathrm{I} \AA$ & I. $837 \AA$ & vw \\
\hline 020 & 7.08 & 7.05 & $\mathrm{~m}$ & $53 \mathrm{I}$ & 1.803 & I. 804 & $\mathrm{vw}$ \\
\hline 130$\}$ & & $\int 4.35$ & & $37^{\circ}$ & & ( 1.780 & \\
\hline 220$\}$ & 4.39 & $\{44$ & W & $07 \mathrm{I}\}$ & I. 779 & 1.774 & $w$ \\
\hline 001 & 3.77 & 3.68 & w & $550)$ & & 1.776 & \\
\hline 230$\}$ & 3.62 & $\{3.63$ & vs & 171 & I. 756 & I. 753 & $\mathrm{w}$ \\
\hline OII $\}$ & 3.02 & 3.63 & vs & $60 \mathrm{I}$ & $1.70 \mathrm{r}$ & 1.700 & $\mathrm{w}$ \\
\hline $\begin{array}{l}040 \\
1 \\
1\end{array}$ & 3.49 & $\left\{\begin{array}{l}3.52 \\
3.46\end{array}\right.$ & $m$ & $\left.\begin{array}{l}3^{12} \\
640\end{array}\right\}$ & I. 677 & $\left\{\begin{array}{l}1.672 \\
1.677\end{array}\right.$ & $\mathrm{m}$ \\
\hline 320 & 3.34 & 3.35 & $\mathrm{~m}$ & $621\}$ & 655 & $\{1.653$ & VW \\
\hline I 2 I & 3.20 & 3.18 & vs & $042\}$ & 1.055 & 1.657 & \\
\hline 201 & 3.10 & 3.14 & $\mathrm{~m}$ & 380 & & $\{1.599$ & vw \\
\hline $2 ! I$ & 3.07 & 3.06 & vw & $631\}$ & I. 597 & I. 598 & W \\
\hline 240$\}$ & 208 & $\{3.00$ & $\mathbf{s}$ & 412 & 1.560 & I. 560 & vw \\
\hline 330$\}$ & 2.98 & $\{2.96$ & $\mathrm{s}$ & $47 \mathrm{I}$ & & (1. 508 & \\
\hline 221 & 2.89 & 2.87 & $\mathrm{~s}$ & $252\}$ & I. 505 & $\{1.507$ & w \\
\hline I3I & 2.83 & 2.84 & vw & $56 \mathrm{I})$ & & 1.502 & \\
\hline $3 \mathrm{II}$ & 263 & $\{2.63$ & ys & $810)$ & & $(I .423$ & \\
\hline 23I\} & 2.03 & $2.6 \mathrm{I}$ & vs & $522\}$ & I. 423 & $\{.42 \mathrm{I}$ & $w$ \\
\hline 250$\}$ & & $\{2.53$ & & 262 & & 1.420 & \\
\hline I 4 I $\}$ & $2.5 \mathrm{I}$ & $\{2.5 I$ & vs & 820 & & I. $40 \mathrm{I}$ & \\
\hline 160 & 2.29 & 2.30 & $\mathrm{w}$ & $29 I$ & I. $40 \mathrm{I}$ & $\{.401$ & vw \\
\hline 510$)$ & & 2.26 & & I. 10.0 & & 1.399 & \\
\hline 051$\}$ & 2.25 & $\{2.25$ & $\mathbf{w}$ & $66 I$ & & (I.377 & \\
\hline $4(1)$ & & 2.25 & & $490\}$ & I. 376 & I. 374 & $w$ \\
\hline I5I & $2.2 \mathrm{I}$ & 2.21 & $w$ & $74 \mathrm{I}$ & & I. 379 & \\
\hline $4^{2} \mathrm{I}$ & 2.16 & 2. 16 & $\mathrm{~m}$ & 172 & I. 361 & I. 363 & $w$ \\
\hline $43 \mathrm{I}$ & 2.04 & 2.05 & $\mathrm{w}$ & & & & \\
\hline 450$\}$ & & $\{2.01$ & & & Unit $\mathrm{c}$ & cell & \\
\hline 360$\}$ & 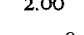 & 2.00 & w & \multirow{6}{*}{\multicolumn{4}{|c|}{$\begin{array}{l}\text { Orthorhombic-(calculated } \\
\text { on } 59 \text { reflections): } \\
\begin{array}{l}a=11.439 \AA \\
b=14.093 \AA \\
c=3.754 \AA\end{array}\end{array}$}} \\
\hline 600 & 1.908 & I. 907 & $\mathrm{~m}$ & & & & \\
\hline 610$\}$ & 1. 892 & $\left\{\begin{array}{l}1.889 \\
.8\end{array}\right.$ & $w$ & & & & \\
\hline 270$\}$ & & 1.899 & $w$ & & & & \\
\hline $\left.\begin{array}{l}26 \mathrm{I} \\
002\end{array}\right\}$ & I. 876 & $\left\{\begin{array}{l}\mathrm{I} .88 \mathrm{I} \\
\mathrm{I} .8 \mathrm{I} 7\end{array}\right.$ & $\mathrm{vw}$ & & & & \\
\hline $\begin{array}{l}0021 \\
620\end{array}$ & 1.855 & $\begin{array}{r}1.817 \\
\quad 1.840\end{array}$ & $\mathrm{vw}$ & & & & \\
\hline
\end{tabular}

higher than chalcopyrite and slightly lower than tetrahedrite. Reflectance and microindentation measurements were made using the Vickers apparatus of the Institute of Geological Sciences of the United Kingdom in London (diamond paste and Texmet final polishing, standard SiC Zeiss I57, Schott continuous interference $\mathrm{Li}-\mathrm{Ne}$ filter). The maximum and minimum values for $R_{1}$ and $R_{2}$ at the four principal wavelengths are listed in Table III. The microindentation hardness (VHN) is between 212 and $222 \mathrm{~kg} / \mathrm{mm}^{2}$ using a $50-\mathrm{g}$ load.

TABLE III. Reflectance measurements in air of garavellite

\begin{tabular}{lll}
\hline$\lambda$ & $R_{1}$ & $R_{2}$ \\
\hline $470 \mathrm{~nm}$ & $33.5-34.7$ & $40.5-42.8$ \\
546 & $32.8-34.7$ & $40.2-42.0$ \\
589 & $32.6-33.7$ & $39 \cdot 3-41.0$ \\
650 & $32.4-346$ & $38.4-41.0$ \\
\hline
\end{tabular}


In reflected light the qualitative features of garavellite easily distinguish it from berthierite, in particular the pink tint of the latter mineral (sample from Braunsdorf, Saxony; polished-section collection of IGS). According to the reflectance and microindentation hardness reported in Ramdohr (1969), Uytenbogaardt and Burke (I97I), and Caye and Pasdeloup (1976), garavellite is a little harder and darker than berthierite.

Preservation of type material. Garavellite-bearing samples mounted in polished section have been deposited at the mineralogical museums of the Universities of Florence and Bari.

Acknowledgements. The authors are pleased to thank $\mathrm{Dr}$ A. Kato, Chairman of IMA Commission on New Minerals and Mineral Names, Professor I. Kostov of the National Natural History Museum of Bulgaria, Dr P. B. Barton, $J r$., of the United States Geological Survey, Professor M. Franzini of Pisa University, and Professors G. P. Bernardini, C. Cipriani, S. Menchetti, and C. Sabelli of the Florence University for their helpful criticism.

We are grateful to Dr S. H. U. Bowie and Mr P. R. Simpson of the Institute of Geological Sciences, London, and Dr N. F. M. Henry of the University of Cambridge for suggestions and assistance with the reflectance determinations.

\section{REFERENCES}

Barton (P. B., jr.), I97I. Econ. Geol. 66, I21-32.

Berry (L. G.) and Thompson (R. M.), 1962. X-ray powder data for ore minerals: The Peacock Atlas. Geol. Soc. Am., Memoir 85.

Buerger (M. J.) and Hahn (T.), I955. Am. Mineral. 40, 22638 .

Capuzzi (Q.) and Carriero (M.), 1973. Il Frantoio, 11, 3-7.
Carmignani (L.), Dessau (G.), and Duchi (G.), I972. Mem. Soc. Geol. Ital. 11, 417-3I. 1975. Boll. Soc. Geol. Ital. 94, 725-58.

Caye (R.) and Pasdeloup (J.), 1976. Card Index COMIMA, n.I. 0780 .

Clark (A. H.), I966. Mineral. Mag. 35, I I 23-5.

Corsini (F.) and Tanelli (G.), 1974. Rend. Soc. Ital. Min. Petr. 30, 205-21.

Craig (J. R.), Barton (P. B., jr.), and Sepenuk (B.), I97I. Geol. Soc. Am. Abstr. Programs, 3, 305 I973. Econ. Geol. 68, 493-506.

D'Achiardi (A.), I88 I. Atti Soc. Tosc. Sci. Nat., Proc. Verb. 2, I7 I -8.

Dallan Nardi(L.) and Nardi (R.), 1975. In Structural model of Italy. Ital. Res. Nat. Council Pub., Roma, 203-56.

Duncumb (P.) and Jones (E. M.), 1969. Tube Investments, Techn. report, n. 260.

Giglia (G.) and Radicati di Brozolo (F.), 1970. Boll. Soc. Geol. Ital. 89, 485-97.

Manasse (E.), 1906. Atti Soc. Tosc. Sci. Nat., Mem. 22, 8 I93.

Monetti (L.), 1924. Rassegna mineraria, 61, II.

Nowacki(W.), 1969. Schweiz. Min. Petrogr. Mitt. 49, 10956.

Palache (C.), Berman (H.), and Frondel (C.), 1944. Dana's system of mineralogy, 7 th edn, 1, Wiley \& Sons, Inc. NY, London.

Ramdohr (P.), 1969. The ore minerals and their intergrowths. Pergamon Press, Oxford.

Sugaki (A.), Shima (H.), and Kitakaze (A.), 1972. Synthetic sulfide minerals $(I V)$, Technology Report Yamaguchi Univ., I, 76-85.

Tanelli (G.), 1970. Periodico Mineral, 39, 56r-83.

Trevisan (L.), Dallan (L.), Federici (P. R.), Giglia (G.), Nardi (R.), and Raggi (G.), I971. Note illustrative Carto Geol. d'Italia, foglio 96, Serv. Geol. It. Roma.

Uytenbogaardt (W.) and Burke (E. A.), 197I. Tables for microscopic identification of ore minerals, Elsevier Publ., Amsterdam.

[Manuscript received 9 August 1978] 